\title{
Kisah Al-Qur'an dalam Tinjauan Sains (Studi atas Serial Tafsir Ilmi Kementerian Agama RI)
}

\author{
Faizin \\ Universitas Islam Negeri Imam Bonjol Padang \\ faizin@uinib.ac.id
}

DOI: $10.29240 /$ alquds.v4i1.1106

Submitted: 2019-09-30| Revised: 2020-03-19|Accepted: 2020-04-13

\begin{abstract}
This article discusses the pattern of integration of religion and science in the book series Tafsir Ilmi "Kisah Nabi Pra-Ibrahim dalam Perspektif Al-Qur'an dan Sains." This descriptive-qualitative research uses the quantum integration theory Nidhal Guessoum (2011) through library research. The results of this study show that there are three patterns of integration that are strictly applied in the work. First, the pattern of integration of the story of the Qur'an and science emphasizes the principle that there is no contradiction between the Qur'an and science, both in terms of source, purpose, method, and content. Second, it can be seen that the application of multiple layered interpretation patterns in the work confirms that there is no single truth in explaining the historical information of human civilization. Third, the theological falsification pattern proves the existence of methodological and metaphysical aspects. The methodological aspect shows that there is a valid presentation of scientific data. The metaphysical aspect of the Qur'anic story advocates the internalization of moralspiritual values for the reader.
\end{abstract}

Keywords: The story of the Qur'an, science, interpretation of science, integration

\begin{abstract}
Abstrak. Artikel ini membahas pola integrasi agama dan sains dalam seri buku Tafsir Ilmi "Kisah Nabi Pra-Ibrabim dalam Perspektif Al-Qur'an dan Sains." Penelitian kualitatifdeskriptif ini menggunakan teori integrasi kuantum Nidhal Guessoum (2011) melalui telaah perpustakaan (library research). Hasil penelitian ini memperlihatkan ada tiga pola integrasi yang diterapkan secara ketat dalam karya tersebut. Pertama, pola integrasi kisah al-Qur'an dan sains menekankan prinsip tidak ada pertentangan antara al-Qur'an dan sains, baik pada sisi sumber, tujuan, metode, maupun konten. Kedua, terlihat adanya penerapan pola penafsiran berlapis dalam karya tersebut yang menegaskan bahwa tidak ada kebenaran tunggal dalam menjelaskan informasi kesejarahan peradaban manusia. Ketiga, pola falsifikasi teistik membuktikan adanya aspek metodologi dan metafisik. Aspek metodologi memperlihatkan adanya penyajian data ilmiah yang valid. Aspek metafisik dari kisah al-Qur'an menganjurkan upaya internalisasi nilai-nilai spiritual moral bagi pembaca.
\end{abstract}


78 | AL QUDS : Jurnal Studi Alquran dan Hadis vol. 4, no 1, 2020

Kata kunci: Kisah al-Qur'an, sains, tafsir ilmu, integrasi.

\section{Pendahuluan}

Selama ini penjelasan kisah-kisah al-Quran hanya disajikan secara naratifdeskriptif dalam kitab-kitab tafsir. Dalam kacamata ulum al-Qur'an tujuan kisah al-Quran cenderung terpaku pada satu titik, yakni mengambil pelajaran dari kisah. Tujuan ini menjadikan produksi teks statis dan tidak memberi banyak dampak bagi perkembangan peradaban manusia. Hal ini lebih disebabkan oleh orientasi studi kisah al-Quran yang cenderung monodisiplin.Meminjam istilah Nasr Hamid Abu Zaid, bahwa dominasi otoritas teks selama ini terbatas pada tradisi keagamaan, dimana turâts dijadikan sebagai satu-satunya pemegang otoritas pengetahuan. ${ }^{1} \mathrm{Hal}$ ini kemudian berimplikasi pada produktivitas teks yang tidak banyak memberi solusi bagi berbagai persoalan kemanusiaan. Untuk keluar dari persoalan tersebut, interaksi dialogis antara kisah al-Quran dan sains dalam wujud integrasi adalah suatu keniscayaan.

Diskursus integrasi keilmuan terus mengalami kemajuan seiring terjadinya shifting paradigm dalam melihat agama dan sains.Kehadiran Tafsir IlmiKementerian Agama RImerupakan wujud nyata dari usaha pemerintah untuk meruntuhkan sekat antara agama dan sains. Ia menjadi bukti bahwa problem dikotomi ilmu tidak lagi ramai diperdebatkan, baik dalam lingkup konsep, teori, maupun penerapan praktis di dunia penelitian. Lebih lanjut kehadiran Tafsir Ilmi dinilai telah memperkuat posisi sains dalam menjelaskan kandungan al-Quran. Eksistensi sains tidak saja menjadi bukti faktual atas kebenaran al-Qur'an, namun turut berkontribusi dalam menjelaskan ayat-ayat al-Quran.

Penelitian ini melihat pola integrasi agama (al-Qur'an) dan sains dalam Beku serial Tafsir Ilmi Kementerian Agama RI: Kisab Para Nabi-Pra Ibrabim dalam Perspektif al-Qur'an dan Sains”. Studi kisah al-Qur'an dalam literatur 'Ulum alQuran cukup ramai diperbincangkan, baik klasik, modern, maupun kontemporer. Namun, studi khusus yang melihat pola integrasi agama dan sains dalam kisah al-Quran pada objek ini belum ditemukan. Studi penulis sebelumnya $(2017)^{2}$ telah melihat pola integrasi al-Quran dan sains dalam tafsir ilmi secara umum. Tidak spesifik mengkaji kisah al-Quran. Penelitian kali ini berupaya memadukan teori Ulum al-Quran tentang kisah al-Quran melalui teori integrasi agama dan sains. Selain objek tafsir ilmi, juga ditemukan penelitian "Dimensi Sains dalam Kisah al-Quran olehYusuf Baihaqi (2018) ${ }^{3}$. Baihaqimenemukan penggunaan kata dalam kisah al-Quran menjadi bukti adanya keterkaitan antara al-Quran dan

\footnotetext{
${ }^{1}$ Nasr Hamid Abu Zaid, Teks Otoritas Kebenaran (Yogyakarta: LKiS, 2012), 10-13.

${ }^{2}$ Faizin, "Integrasi Agama Dan Sains Dalam Tafsir Ilmi Kementerian Agama RI," Jurnal Ushuluddin 25, no. 1 (2017): 19-33, doi:10.24014/jush.v25i1.2560.

${ }^{3}$ Yusuf Baihaqi, "Dimensi Sains Dalam Kisah Al-Qur'an Dan Relevansinya Dengan Keakuratan Pemilihan Kata," Jurnal Aqlam 3, no. 2 (2018): 266-80.
} 
sains. Dalam hal ini, Baihaqi tidak menggunakan pola integrasi dalam memahami pilihan kata yang digunakan al-Quran dalam mengungkap dimensi sains kisah alQuran.

Penelitian ini menggunakan metode kualitatif-deskriptif melalui telaah perpustakaan (library research). Penelitian ini menerapkanteoriintegrasiagama dan sains yang bersinergi dengan teori 'Ulum al-Qur'an. Secara spesifik penelitian ini menggunakan teori integrasi agama dan sains NidhalGuessoum (2011) yang ia sebut dengan teori rekonsiliasi. ${ }^{4}$ Dalam praktiknya, teori ini memakai pendekatan kuantum, yakni sistem kerja bolak-balik dengan mengikuti tiga pola integrasi. ${ }^{5}$ Pertama, al-Quran dan sains tidak bertentangan karena memiliki kesamaan sumber, tujuan, metode, dan konten. Kedua, penafsiran berlapis (multiple levels of reading), yakni menghindari kebenaran tunggal dengan melakukan penafsiran secara bertingkat dan berlapis sesuai dengan kapasitasintelektual mufasir. Ketiga, falsifikasi teistik, yakni penggunaan metode ilmiah dalam Tafsir Ilmiserta penyimpulan aspek metafisis melaluiworldvienteistik agar terungkap sisi teologis.

Penelitian ini bertujuan menganalisis pola integrasi kisah al-Qur'an dan sains dalam Tafsir Ilmi: Kisah Para Nabi Pra-Ibrabim dalam Perspektif al-Qur'an dan Sains. Berdasarkan teori integrasi di atas, ada tiga aspek yang ingin dibuktikan, yakni: [1] apakah tidak ada pertentangan antara kisah al-Qu'an dengan sains dalam serial Tafsir Ilmi, [2] apakah dalam serial Tafsir Ilmi tersebut terdapat pola penafsiran berlapis yang dilakukan pengarang dalam mengungkap kebenaran kisah al-Qur'an, dan [3] bagaimana falsifikasi teistis diposisikan dalam serial Tafsir Immi tersebut, baik pada aspek metodologi maupun metafisik.

\section{Kisah al-Qur'an}

Secara etimologi term "kisah" berasal dari bahasa Arab, yakni qishshabdan qashash. Ia merupakan bentuk mashdar (infinitif) dari qashsha-yaqushshu yang berarti tatubbi' al-syai (menelusuri sesuatu) atau tatubbi' al-' 'atsar (mengikuti jejak). Makna ini senada dengan kandungan surat al-Kahfi/18 ayat 64: "Musa berkata: "Itulah (tempat) yang kita cari." Lalu keduanya kembali, mengikuti jejak, mereka

\footnotetext{
${ }^{4}$ Nidhal Guessoum, Islam's Quantum Question: Reconciling Muslim Tradition and Modern Science (London: I.B. Tauris, 2011).

${ }^{5}$ Achmad Khudori Soleh, "Pendekatan Kuantum Dalam Integrasi Agama Dan Sains Nidhal Guessoum," ULUL ALBAB Jurnal Studi Islam 19, no. 1 (2018): 119, doi:10.18860/ua.v19i1.4937.

${ }^{6}$ Muhammad Abi al-Husain Ahmad Ibn Fâris Ibn Zakaria, Mu'jam Maqâyiz al-Lughah (Beirut: Dar Ihya al-Turats Arabi, 2001), 826.

7Al-Raghib al-Asfahaniy, Mufradât Alfâz, Al-Qur'ân (Damaskus: Dar al-'Ilm, 2002), 671.
} 
semula." Artinya kembali menjejaki jalan yang pernah ditempuh sebelumnya. Makna ini memberikan gambaran bahwa kisah al-Qur'an mesti ditelusuri akar sejarahnya untuk kemudian diikuti oleh generasi-generasi setelahnya.

Secara terminologi, menurut Mannâ' al-Qaththân, kisah al-Qur'an adalah berita-berita yang disampaikan al-Qur'an mengenai keadaan umat-umat terdahulu, para nabi-nabi terdahulu dan peristiwa-peristiwa lainnya yang pernah terjadi pada masa lalu. ${ }^{8}$ Dari definisi kisah secara etimologi dan terminologi di atas dapat ditarik benang merah bahwa pembacaan atas kisah merupakan salah satu jalan untuk menelusuri jejak peristiwa masa lampau yang disebut di dalam al-Qur'an, baik keadaan umat terdahulu, para nabi, maupun peristiwa silam yang benar-benar pernah terjadi. Jika mengikuti makna surat al-Kahfi/18 ayat 64, maka secara sederhana kisah tersebut berfungsi sebagai pedoman bagi manusia, baik untuk diikuti ataupun dihindari.

Di dalam al-Qur'an term qashash berikut derivasinya terulang sebanyak 26 kali, baik dalam bentuk al-ism (kata benda) maupun al-fi'l(kata kerja). Dalam bentuk kata benda terulang sebanyak enam kali pada lima surat, yakni Ali Imrân /3:62; al-A'râf /7: 176; Yusuf /12: 3 dan 111; al-Kahfi /18: 64 dan al-Qashash /28: 25, semua diungkap dalam bentuk jama'. Sementara dalam bentuk kata kerja diungkap sebanyak 20 kali, empat dalam bentuk fi'l al-mâdiy: al-Nisâ'/4: 164; alNahl/16: 118; al-Qashash/28: 25; dan Gâfir/40: 78, 12 kali dalam bentuk fi'il almudhari' terdapat dalam delapan surat, yakni:al-Nisâ'/4: 164; al-An'âm/6: 57 dan 130; al-A'râf/ 7; 7, 35 dan 101, Hûd/11: 100 dan 120; Yûsûf/12: 3 dan 5; alKahfi/18: 13; al-Naml/27:76; Gâfir/40:78, dua kali dalam bentuk fi'il al-amr, yakni: al-A'râf/ 7; 176; dan al-Qashash/28: 11. ${ }^{9}$

Dari semua ayat yang menggunakan term qashash di atas, setidaknya memiliki empat konten terkait dengan kisah al-Qur'an, yakni: hakikat kebenaran kisah al-Qur'an, fungsi kisah al-Qur'an, term qashash sebagai bentuk ungkapan yang digunakan dalam kisah itu sendiri, dan fungsi rasul sebagai subjek penyampai ayat-ayat Allah. Untuk menjelaskan posisi kebenaran kisah, al-Qur'an menggunakan kata al-haqq. Ini terdapatdalam QS. Ali Imrân/3 ayat 62:

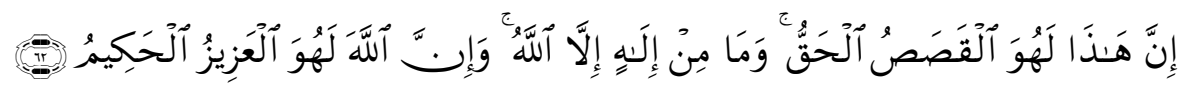

Sesunggubnya ini adalah kisah yang benar, dan tak ada Tuban selain Allab; dan Sesungsubnya Allah, Dialah yang Maha Perkasa lagi Maha Bijaksana.

300.

${ }^{8}$ Manna al-Qaththân, Mababits Fi 'Ulum al-Qur'An (Kairo: Maktabah Wahbah, 2000),

${ }^{9}$ Muhammad Fu'ad Abd al-Baqi, Al-Mu'jam al-Mufahras Li Alfaz̧h al-Qur'an al-Karim (Beirut: Dar Al-Fikr, 1417), 546. 
Kata baqq menurut Ibn Fâris menunjukkan kokoh dan benarnya sesuatu. ${ }^{10}$ Kebenaran yang dibawa oleh term al-haqq mengindikasikan kepastian, dimana berita yang disebut tidak mengandung keraguan sedikitpun. ${ }^{11}$ Jika dikaitkan dengan ayat sebelumnya (Ali Imran/3: 60) bahwa "Kebenaran itudatang dari Tubanmu, karena itu janganlah kamu termasuk orang-orang yang ragu-ragu". Disini landasan kebenaran kisah al-Qur'an berangkat sumber berita, yakni wahyu Allah. Nur al-Dîn Muhammad 'Itr menjelaskan bahwa pengetahuan tentang peristiwa masa lampau tidak dimuat dalam dokumen sejarah; tidak ditulis dalam manuskrip manapun. Ia justru diungkap oleh al-Qur'an yang merupakan wahyu dari Allah. ${ }^{12}$ Ini menunjukkan bahwa kebenaran kisah al-Qur'an adalah kebenaran mutlak.

Penyebutan kisah sebagai sesuatu kebenaran kemudian dikaitkan dengan Keesaan, Keperkasaan dan Kebijaksanaan Allah SWT. Artinya nilai kebenaran kisah al-Qur'an terkait erat dengan nilai-nilai ketuhanan. RasyîdRidhâ (w 1354 H) menjelaskan bahwa kebenaran pengisahan al-Qur'an tentang Nabi Isâ (QS. Ali Imran/3: 59-61) adalah bantahan terhadap keyakinan kaum Nasrani yang menganggap Isâ adalah Tuhan atau anak Tuhan dan bantahan terhadap kaum Yahudi yang menistakan Isâ sebagai anak zina. ${ }^{13} \mathrm{Hal}$ ini sekaligus menyucikan bahwa Allah tidak ada yang menyerupai-Nya dan kemudian menempatkan kebenaran kisah al-Qur'an sebagai bagian yang tak terpisah kebijaksanaan-Nya.

Kebenaran kisah al-Qur'an ini dipertegas pula oleh QS. Yûsûf /12: 111 yang menyatakan bahwa ia "bukanlah cerita yang dibuat-buat, akan tetapi membenarkan (kitab-kitab) yang sebelumnya".Ini merupakan bantahan pendapat yang menyatakan bahwa kisah al-Qur'an adalah fiksi, khayalan, dongeng dan tidak dapat dibuktikan secara ilmiah. Salah satu pembuktian ayat di atas dalam temuan ilmiah adalah penemuan kota Irâm oleh Nicholas Clapp, sebagaimana terdapat dalam QS. al-Fajr/89: 6-8 atau penemuan reruntuhan bendungan Sad Ma'ribdi Yaman Selatan terkait dengan kaum Saba' dalam QS. Saba'/34: $15 .{ }^{14}$ Artinya, kebenaran kisah al-Qur'an dapat diakui secara material dan faktual. Meskipun dari sekian banyak ayat al-Qur'an yang berbicara tentang kisah umat terdahulu masih banyak juga yang tidak atau belum dibuktikan secara ilmiah.

10 Ahmad Ibn Fâris Ibn Zakaria, Mu'jam Maqâyiz al-Lughah, 227.

${ }^{11}$ Jalâl al-Dîn Muhammad Ibn Ahmad al-Mahalli and Jalâl al-Dîn 'Abdurrahman Ibn Abi Bakr al-Suyûthî, Tafsir Jalalain (Kairo: Dar al-Hadits, n.d.), j. 1, 75.

${ }^{12}$ Nur al-Dîn Muhammad 'Itr, 'Ulum al-Qur'an al-Karim (Damaskus: Mathba'ah Shabâh, 1995), 245.

${ }^{13}$ Muhammad Rasyid Ridha, Tafsìr Al-Manar (Mesir: Hai'ah Mishriyah, 1990), j. 3, 267.; dan Ahmad Ibn al-Musthafâ al-Maraghi, Tafsir Al-Maraghi (Mesir: al-Bâb al-Halabî, 1946), j. 3, 267.

${ }^{14}$ M. Quraish Shihab, Kaedab Tafsir (Tangerang: Lentera Hati, 2013), 329. 
Selain itu, ada sikap cendekiawan yang menilai kisah sebagai sesuatu yang simbolik. Artinya, secara material kisah tersebut dapat diakui kebenarannya namun secara faktual dianggap tidak pernah terjadi. Ulama yang berpendirian semacam ini menurut Quraish Shihab bukan berarti menolak kebenaran kisah al-Qur'an, namun berupaya memalingkan makna haqiqikepada makna majazi. ${ }^{15}$ Kisah Nabi Isâ yang menghidupkan orang mati, dipahami sebagai menghidupkan hati yang mati, bukan berpisahnya ruh dan jasad. Pendapat semacam ini tentu akan terbantah dengan sendirinya jika dihadapkan dengan kebenaran faktual. Namun sejauh mana kebenaran faktual itu dapat dibuktikan karena kisah al-Qur'an bersifat historis dan normatif.

Ada banyak pendapat ulama yang menjelaskan maksud dan tujuan kisahkisah al-Qur'an, secara singkat dapat dijelaskan sebagai berikut: [1] Menjelaskan prinsip dasar dakwah menuju Allah dan memaparkan pokok-pokok syariat yang dibawa oleh para nabi, [2] Meneguhkan hati Nabi Muhammad, [3] Membenarkan para nabi terdahulu, [4] Menampakkan kebenaran Nabi Muhammad, [5] Mengungkap kebohongan abl al-kitâb dengan argumentasi yang membeberkan keterangan dan petunjuk yang mereka sembunyikan, dan [6] Sebagai salah satu cara untuk menyampaikan pesan-pesan moral dan pengajaran bagi manusia, dan lain-lain. ${ }^{16}$

Dari 26 ayat yang memuat kata qashashditemukan beberapa tujuan penyampaian kisah-kisah al-Qur'an, di antaranya: pertama, sebagai bukti kenabian Muhammad SAW (QS. Al-An'âm/6 :57), Kedua meneguhkan hati Muhammad SAW (QS. Hûd/11: 120), dan ketiga sebagai pelajaran bagi manusia yang berfikir dan membenarkan kitab sebelumnya (QS. Yusuf /12: 111). Menarik diungkap lebih lanjut tujuan kisah yang disebut terakhir, yakni sebagai ibrah bagi ûti alalbâb:

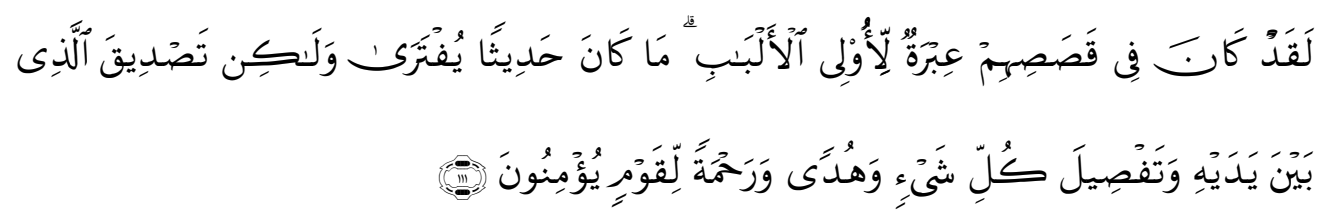

Sesunggubnya pada kisah-kisah mereka itu terdapat pengajaran bagi orang-orang yang mempunyai akal. Al Quran itu bukanlah cerita yang dibuat-buat, akan tetapi membenarkan (kitab-kitab) yang sebelumnya dan menjelaskan segala sesuatu, dan sebagai petunjuk dan rahmat bagi kaum yang beriman.

${ }^{15}$ Ibid., 326.

16al-Qaththân, Mabahits Fi 'Ulum al-Qur'An, 307.; 'Itr, 'Ulum al-Qur'an al-Karim, j. 1, 245.; Abu Ishaq Ahmad Ibn Muhammad Ibn Ibrâhîm al-Naisabûri, Qashash Al-Anbiya' (Beirut: Dar Al-Fikr, n.d.), 1-2.; dan Asâmah Muhammad Abdul 'Azhîm Hamzah, Al-Qashash al-Qur'anî Wa Atsarubu Fi Isbâth al-Ahkâm (Kairo, 2008), 16-20. 
Tbrah dalam bahasa Indonesia sering diterjemahkan sebagai pengajaran atau pelajaran. Al-Râghîb al-Asfahâni menjelaskan bahwa kata ibrah terambil dari 'ibr artinya melampaui sesuatu. I'tibaratau ibrah sendiri dapat diartikan sebagai terbuktinya pengetahuan secara konkrit akan menyingkap pengetahuan yang abstrak. ${ }^{17}$ Artinya, substansi pengajaran itu tidak terletak pada objek yang diamati, namun dibalik objek secara abstrak. Jika pada kisah al-Qur'an terdapat pengajaran, maka pengajaran itu bukanlah objek secara empiris, namun kandungan nilai-nilai yang disuguhkan oleh objek. Substansi sains tidak terletak pada pemaparan temuan ilmiah terhadap kisah al-Qur'an sebagai bukti konkrit nya, akan tetapi terletak pada nilai-nilai pengajaran.

Pengajaran itu menurut ayat di atas hanya mampu ditangkap oleh orang yang memiliki akal murni atau sempurna (ulû al-albâb). Hal ini tidak terlepas dari makna kisah secara etimologi seperti yang disebut di atas, yakni "penelusuran jejak". Buah penelusuran jejak-jejak dari kisah al-Qur'an dengan menggunakan fakta ilmiah ataupun rasionalitas manusia, dapat mengungkap nilai-nilai, baik untuk diikuti ataupun dihindari. Nilai-nilai tersebut dapat berupa nilai ketuhanan (tauhid/spiritual) dan nilai moral (akhlak), nilai pendidikan, dan lain-lain. Nilai ketuhanan misalnya dalam kisah penyembelihan sapi betina dalam QS. alBaqarah/ 2 ayat 67-70, bahwa penyembahan patung sapi oleh orang-orang Isra'il berakhir dengan adanya penyembelihan sapi yang mereka lakukan sendiri. Artinya simbol tuhan berupa sapi yang selama ini mereka yakini telah mati.

\section{Deskripsi Singkat Tafsir Ilmi: Kisah Para Nabi Pra-Ibrahim dalam Perspektif al-Qur'an dan Sains}

Tafsir Ilmi Kementerian Agama buku serial dari hasil integrasi tafsir alQur'an dengan sains yang diinisasioleh Lajnah Pentashihan Mushaf al-Qur'an (LPMA) Bidang Litbang dan Diklat Kementerian Agama RI bekerjasama dengan Lembaga Ilmu Pengetahuan Indonesia (LIPI).

Kehadiran Tafsir Ilmi di tengah-tengah masyarakat Indonesia dilatarbelakangi oleh beberapa alasan yang mendasar, yakni: [1] respon terhadap perkembangan ilmu pengetahuan dan teknologi, [2] kesadaran iqra' sebagai upaya pengkajian terhadap al-Qur'an melalui ilmu pengetahuan modern yang bertujuan memperkokoh keimanan, [3] sebagai salah satu model mengenalkan Tuhan kepada manusia modern, dan [4] menjadikan al-Qur'an sebagai paradigma dan dasar yang memberi makna spiritual kepada ilmu pengetahuan \&

${ }^{17}$ al-Asfahaniy, Mufradât Alfẫ. Al-Qur'ân, 543.; Ibn Fâris berpendapat bahwa makna asal dari ibritu adalah menembus dan melintas. Ahmad Ibn Fâris Ibn Zakaria, Mu’jam Maqâyiz alLughah, 702. 
teknologi agar tidak bebas nilai dan sekuler. ${ }^{18}$ Latar belakang penulisan Tafsir Ilmi di atas setidaknya memiliki tiga wilayah kerja ilmu secara sinergis, yaitu: [1] menanamkan nilai-nilai transendental melalui pembacaan al-Qur'an dan sains, yang diharapkan mampu menggugah dan mengukuhkan keyakinan manusia untuk meyakini kebesaran Tuhan, [2] adanya keinginan untuk memberikan aksiologi ilmu bagi sains modern agar tidak bebas nilai dan tatap berada pada pusaran etika ilmu pengetahuan, dan [3] ingin menunjukkan secara eksplisit adanya integrasi keilmuan, khususnya antara Islam (tafsir al-Qur'an) dan temuan ilmiah. Selain latar belakang di atas, penulisan Tafsir Ilmi juga dimotivasi oleh adanya keinginan untuk membangun peradaban Islam yang digagas melalui perjumpaan ilmu pengetahuan dan tafsir. ${ }^{19}$

Otoritas Tafsir Ilmi sebagai produk integrasi sains dan al-Qur'an dapat dilihat dari author (baca: tim penulis) yang ikut terlibat dalam penulisan. Tim penulis karya momental ini terdiri dari tim syar'idan tim kauni. Tim syar'i terdiri dari ulama al-Qur'an yang diketahui telah lama dan banyak bergelut di bidang alQur'an dan tafsirnya, umumnya mereka berasal dari kalangan akademisi, seperti Ahsin Sakho Muhammad, Syibli Sarjaya, Muchlis M. Hanafi, Hamdani Anwar, dan Darwis Hude. Sementara tim kauni adalah para saintis yang berasal dari Lembaga Ilmu Pengetahuan Indonesia (LIPI), Lembaga Pengembangan dan Antariksa Nasional (LAPAN), dan Bosscha Institut Teknologi Bandung (ITB), mereka adalah para ilmuwan dan akademisi yang cukup dikenal Indonesia dengan beragam latar belakang keilmuan, di antaranya: Herry Harjono, Thomas Djamaluddin, Mudji Haharto, Umar Anggara Jenie, Arie Budiman dan lain-lain. Artinya kolaborasi antara ulama al-Qur'an dan saintis dipandang kapabel dalam memproduksi Tafsir Ilmi. Hal ini kemudian ditunjang oleh sistem kerja sama yang baik melalui ijtihad kolektif (ijtihad jamẩi $)^{20}$ dan semua tim tunduk pada prinsip dasar penyusunan tafsir ilmi yang telah dirumuskan. ${ }^{21}$

${ }^{18}$ Semua karya Tafsir Ilmi memuat sambutan dari beberapa institusi terlibat, kecuali terbitan tahun 2010 yang tidak memuat sambutan menteri agama. Lihat: Lajnah Pentashihan Mushaf al-Qur'an, Hewan Dalam Perspektif Al-Qur'an Dan Sains (Jakarta: LPMA, 2012), ix-xviii.

${ }^{19}$ Muchlis M. Hanafi, "Memahami Isyarat-Isyarat Ilmiah al-Qur'an: Sebuah Pengantar," in Kisah Para Nabi Pra-Ibrabim Dalam Perspektif al-Qur'an Dan Sains, by Lajnah Pentashihan Mushaf al-Qur'an (Jakarta: LPMA, 2012), xxii.

${ }^{20}$ Lajnah Pentashihan Mushaf al-Qur'an, Kisah Para Nabi Pra-Ibrabim Dalam Perspektif alQur'an Dan Sains (Jakarta: LPMA, 2012), xii, xiv, xviii.

${ }^{21}$ Menurut Muchlis M. Hanafi, ada tujuh prinsip dasar penyusunan Tafsir Ilmi, secara ringkas dapat disebutkan sebagai berikut [1] Memperhatikan arti dan kaedah kebahasaan, [2] Memperhatikan konteks ayat yang ditafsirkan. [3] Memperhatikan hasil penafsiran Rasul, sahabat, tabi'in, dan ulama tafsir, serta memahami ulum al-Qur'an, [4] Tidak menggunakan ayat untuk menghukum benar atau salah sebuah temuan ilmiah, [5] Memperhatikan makna musytarak dari sebuah kata, [6] Memahami isyarat ilmiah hendaknya memahami benar objek bahasan ayat, dan [7] Menggunakan temuan ilmiah yang telah mencapai tingkat hakikat, bukan teori atau 
Mengenai seri buku Kisab Para Nabi Pra-Ibrabim dalam Perspektif al-Qur'an dan Sains, memuat beberapa kisah terkait, yakni: Nabi Adam, Idris, Nuh, Hud dan Salih, baik dari aspek pemaparan kisah al-Qur'an maupun dari aspek kronologi kisah tersebut dalam kaitannya dengan sejarah peradaban manusia. Sebelum menguraikan lebih lanjut tentang dua aspek di atas, terlebih dahulu dijelaskan tentang kisah al-Qur'an dalam pandangan ulum al-Qur'an, baik dari sisi maksud dan tujuan kisah, kisah al-Qur'an sebagai fakta sejarah, gaya penyampaian kisah, maupun posisi israiliyat dalam kisah al-Qur'an. Selain itu, sisi keberadaan Nabi dan Rasul juga dijelaskan untuk memperkuat eksistensi kisah Para Nabi Pra-Ibrahim. Bahasan ini meliputi tiga aspek penting yang disusun secara sistematis yang bertujuan membuktikan eksistensi Nabi dan Rasul itu, yakni: keraguan akan keberadaan Nabi dan Rasul, Pembuktian keberadaan Nabi dan Rasul, dan sejarah umat manusia dan kebudayaannya. ${ }^{22}$

\section{Pola Integrasi al-Qur'an dan Sains dalam Kisah al-Qur'an}

Mengikuti teori rekonsiliasi Nidhal Guessoum melalui pendekatan kuantum, bahasan ini menganalisa penerapan pola integrasi dalam serial Tafsir Ilmi: Kisah Para Nabi Pra-Ibrabim. Berikut rincian masing-masing:

\section{Kisah al-Quran Tidak Bertentangan dengan Sains}

Guessoum ketika menjelaskan paradigma adanya titik pertemuan antara agama dan sains menyatakan bahwa keduanya merupakan "bosom sisters" (saudara sepersusuan). Keduanya selaras dan tidak bertentangan satu sama lain, baik dari sisi sumber, tujuan, metode, maupun kontens. Pertama, dari sisi sumber, kisah alQuran berasal dari wahyu yang merupakan ayat qauliyah. Sementara sains berasal alam yang merupakan ayat kauniyah. Keduanya akan bermuara pada sumber yang sama, yakni Tuhan. Secara logis, keduanya tidak mungkin bertentangan. Paradigma inilah yang kemudian ditemukan dalam Tasir Ilmi.

Pandangan bahwa kisah al-Qur'an tidak berseberangan dengan temuan sains diungkap dalam serial Tafsir Ilmi. Beberapa temuan arkeologis yang relevan dengan kisah al-Qur'an dijadikan oleh pengarang sebagai buktikebenaran kisah al-Quran.Seperti, kisah al-Qur'an dalam QS. Al-Fajr/89:6-9, pengarang menggunakan bukti arkeologis penemuan prasasti Ebla dan sisa-sisa kota Iram. Penemuan prasasti Ebla oleh Giovani Pettinato dan Father Dahood dalam tahun 1964-1979, menurut pengarang, membuktikan eksistensi kaum 'Ad di

hipotesis yang belum teruji. Lihat: Hanafi, "Memahami Isyarat-Isyarat Ilmiah al-Qur'an: Sebuah Pengantar," xxv-xxvii.

${ }^{22}$ Lajnah Pentashihan Mushaf al-Qur'an, Kisah Para Nabi Pra-Ibrabim Dalam Perspektif alQur'an Dan Sains. 
Kota Iram. Melalui penemuan ini diketahui prasasti Ebla berumur sekitar 4.500 tahun. Umur ini sama dengan umur kaum 'Ad dan Samud menurut tradisi tarikh Arab Purba. ${ }^{23}$

Selain Prasasti Ebla, Nicholas Clapp dan JurisZarins pada tahun 1984 dibantu oleh NASA dan didukung oleh teknologi satelit yang menggunakan optical sensing system milik Prancis, melakukan pemotretan di sekitar Arabia Selatan. Analis foto-foto hasil pemotretan menunjukkan pada kedalaman \pm 200 meter, kemungkinan ada kota tua yang terbenam. Berbekal citra ini, pada tahun 1992, Clapp melakukan penggalian dan berhasil menemukan bukti arkeologi dalam bentuk bangunan segi delapan dilengkapi oleh menara dan dindingdinding yang tinggi. ${ }^{24}$

Karena kisah al-Qur'an berkaitan dengan sejarah, umumnya interaksi dialogis antara kisah al-Quran dan sains dilihat dari kajian arkeologis. Meskipun demikian, hanya segelintir dari temuan arkeologis yang dapat dijadikan sebagai penjelasan kisah al-Qur'an itu. Kisah Nabi Idris, misalnya, tidak mendapat penjelasan sains dalam Tafsir Ilmi. Hal ini bisa jadi dikarenakan adanya keterbatasan sains dalam mengungkap sejarah Nabi Idris di satu sisi. Di sisi lain, penjelasan al-Qur'an tentang Nabi Idris juga tidak seperti pengungkapan kasih Nabi-nabi yang lain. Penyebutan Nabi Idris dalam al-Qur'an terdapat pada dua ayat, yakni Surat al-Anbiyâ' ayat 84 dan $85 .{ }^{25}$ Pada ayat 84 menjelaskan kredibilitas Idris sebagai nabi yang mencintai kebenaran. Sementara ayat 85 menjelaskan keutamaan tiga Nabi, yakni Ismail, Idris dan Zulkifli. Artinya, tidak semua penyebutan Nabi di dalam al-Quran merupakan bagian peristiwa yang pernah terjadi. Bisa jadi hal tersebut merupakan penjelasan eksistensi Nabi. Hal ini turut mengukuhkan prinsip keterkaitan antara kisah al-Qur'an dan sains. Dalam arti kata, keterbatasan data pada satu sumber menyebabkan sumber yang lain tidak bisa diungkapkan.

Kedua, dari sisi tujuan, kisah al-Qur'an dan sains memiliki tujuan yang sama, yakni menjadi pengajaran (ibrab) bagi umat di masa mendatang. Hal ini sebagaimana dijelaskan dalam Qs. Yusuf/12:111. Misalnya, ketika menjelaskan usia Nabi Nuh, dikutip QS. al-'Ankabut/29: 14-15 yang menyebutkan bahwa usia Nabi Nuh 950 tahun. Hal ini kemudian diperkuat dengan hasil temuanBalsiger dan Sellier,bahwa sebelum banjir besar datang, atmosfer masih diselimuti oleh lapisan kanopi air yang berfungsi melindungi manusia dari radiasi ultraviolet. Setelah banjir besar kanopi ini turun ke bumi yang mengakibatkan lapisan atmosfer menjadi tipis dan mengakibatkan umur manusia menjadi lebih

\footnotetext{
${ }^{23}$ Ibid., 92-93.

24Ibid., 93-98.

${ }^{25}$ Ibid., 52.
} 
pendek, seperti Nabi Ibrahim, hanya berusia 100 tahun. ${ }^{26}$ Kedua penjelasan ini bertujuan agar manusia mampu menempatkan kisah al-Quran dan sains sebagai rambu-rambu dalam menjaga keberlangsungan kehidupan di bumi harus. Karena Pasca Nabi Nuh lapisan atmosfirsemakin sangat tipis yang menyiratkan pentingnya memelihara lingkungan agar atmosfer tetap berfungsi memantulkan radiasi sinar ultraviolet. ${ }^{27}$

Ketiga, kisah al-Quran dan sains tidak bertentangan dari sisi metode. Bagi Guessoum karakteristik sains terletak pada penerapan metode ilmiah. Guessoum meyakini, ketika adanya perpaduan antara metode dialektika dalam agama, metode demonstratif dalam filsafat, serta metode empiris dalam sains akan membuahkan ilmu yang valid. Kisah para Nabi pra-Ibrahim dalam tafsir Ilmi, diungkapkan dengan menggunakan ilmu arkeologi. Ilmu arkeologi secara metodologi menempuh tiga proses tahapan tersebut. Metode penelitian arkeologi dapat meliputi: studi literatur, survey, ekskavasi. ${ }^{28}$ Penggunaan metode penelitian arkeologi dalam seri Tafsir Ilmi tidak sampai pada tahapan survey dan ekskavasi. Ia hanya sampai pada tahapan studi literatur untuk tujuan pengumpulan, pengolahan dan analisis data.

Pada tahapan pengumpulan data, kisah Al-Qur'an ditempatkan sebagai data arkeologi yang perlu dikaji dan diteliti secara ilmiah. Pada proses pengolahan data, ayat-ayat terkait dianalisis dengan menggunakan teori dan konsep tertentu. Selain tahapan tersebut ilmu arkeologi juga menggunakan pendekatan hermeneutika dalam tradisi tafsir untuk menganalisisayat-ayat kisah al-Qur'anterkait. ${ }^{29}$ Sementara data survey dan ekskavasi diambil dari data-data hasil penelitian arkeologi yang pernah ada, karena memang buku ini bukanlah laporan hasil penelitian arkeologi. Tafsir Ilmi lebih dekat dengan studi literatur atau literature review. Meskipun demikian, data-data yang digunakan adalah datadata yang telah menempuh proses dan tahapan metode ilmiah sehingga ia dapat dipertanggungjawabkan.

Dapat disimpulkan bahwa penyajian kisah para Nabi pra-Ibrahim dalam Tafsir Ilmi tidak bertentangan dengan sains (ilmu arkeologi) dari sisi metode. Terlihat adanya interaksi dialogis antara metode ilmu arkeologi dalam menyingkap kisah al-Quran. Kehadiran sains sebagai fakta ilmiah dapat menjadi bukti faktual kisah al-Qur'an. Karena kehadiran sains dalam pandangan Islam bukanlah sesuatu yang independen. Sains dapat berdialog dengan teks, berkolaborasi secara sinergis mengungkap fakta sejarah kisah al-Quran.

26Ibid., 72.

${ }^{27}$ Ibid.

${ }^{28}$ Ibid., 17-18.

${ }^{29}$ Ibid., 17. 
Keempat, tidak ada pertentangan kisah al-Qur'an dan temuan sains dari sisi konten. Benang merah adanya kesamaan konten ini, berangkat dari paradigma al-Qur'an memerintahkan manusia untuk melakukan pengamatan terhadap peristiwa sejarah umat terdahulu dan alam semesta. Pengamatan pada kisah al-Quran, sebagaimana dijelaskan dalam Qs. Yunus/12:109, ${ }^{30}$ akan menghasilkan pengetahuan dan pengajaran bagi umat berikutnya. Pengamatan alam semesta akan melahirkan sains. Dengan menggunakan metode pengamatan pada kedua objek ini secara sinergi akan memperkuat posisi kebenaran alQur'an.

Pengungkapan Tafsir Ilmi tentang fakta sejarah melalui penelitian arkeologi tentang kisah Nabi Nuh, ditarik dari beberapa ayat relevan. Misalnya, QS. Hûd/11: 44 mengenai tempat berlabuh bahtera Nabi Nuh. Dalam ayat ini secara jelas di sebutkan: "babtera itupun berlabuh di atas bukit al-Jûdiy." Pengarang Tafsir Ilmi kemudian menghadirkan data-data temuan arkeologis terkait. Adalah tim ekspedisi yang dipimpin oleh David Fasold dan Salih Bayraktutan berhasil mengungkap fakta sejarah di bukit Judi tersebut pada tahun 1994. Tim ini berhasil mengambil foto sebuah objek berbentuk kapal di Gunung Judi. Objek ini diperkirakan terkubur di kedalaman 2.3000 meter, dengan panjang 170 meter dan lebar 45 meter. Selain itu, dijelaskan temuan sebuah batu besar yang dipahat di ujungnya. Batu tersebut biasanya pada kapal kuno digunakan sebagai kendali yang diletakkan di belakang kapal untuk menjaga keseimbangan. ${ }^{31}$

\section{Penafsiran berlapis (multiple levels of reading)}

Guessoum menyarankan agar tidak terjadi klaim tunggal kebenaran atas sesuatu objek, perlu dilakukan pembacaan teks secara berlapis. Ini berguna mengungkap aspek integrasi secara komprehensif.Multiple levels of reading dalam konteks integrasi sains dan kisah al-Qur'an menghendaki adanya penyajian data yang kompleks dan rigid. Data-data tersebut bisa bersumber dari tradisi tafsir dan bisa dari temuan sains yang dipandang valid serta sumber kitab suci lain:

Pertama, beberapa penjelasan kisah Nabi dianalisis dari berbagai sudut pandang penafsiran. Sebagai contoh, penafsiran tentang tempat turunnya nabi Adam dan Hawa yang dijelaskan dalam Qs. Al-Baqarah/2: 36 dan Thaha/20: 123. Untuk menjelaskan hal ini, tim penyusun menyajikan berbagai pandangan mufasir, di antaranya: [1] pendapat Ibn 'Abbas, Adam turun di Dajna (Dahna), Semenanjung Arabia yang terletak antara Mekah dan Ta'if, [2] pendapat Ibn Abi Hatim dari Ibn 'Umar, Adam turun di bukit Safa dan Hawa di bukit Marwa, [3] riwayat Abu Hurairah, Ibn 'Abbas, Ibn Umar, Adam turun di India tepatnya di

${ }^{30}$ Lihat juga: Qs. al-Rum/30:9; Fathir/35:44; Ghafir/40:21, 82; dan Muhammad/47:

${ }^{31}$ Lajnah Pentashihan Mushaf al-Qur'an, Kisah Para Nabi Pra-Ibrabim Dalam Perspektif alQur'an Dan Sains, 66-71. 
puncak Everest di pegunungan Himalaya, dan Hawa turun di Jeddah, dan [4] pendapat Syauqi Abu Khalil, Adam turun di Sri Langka di gunung Bauz berdasarkan temuan "tapak kaki suci"di gunang itu dengan panjang 1.8 meter. Empat pendapat ini disajikan guna menegaskan bahwa tidak ada kebenaran tunggal pada hasil penafsiran tentang kisah. Meskipun dikatakan bahwa pendapat ketiga paling kuat, bukan berarti mengabaikan pendapat lain. Sebab, tidak atau belum ditemukan bukti arkeologis yang dapat meyakinkan tempat pasti Nabi Adam dan Hawa di turunkan.

Kedua, penjelasan kisah al-Qur'an dijelaskan oleh temuan sains. Sebagaimana dijelaskan sebelumnya bahwa Tafsir Ilmi merupakan hasil perpaduan tafsir dan temuan ilmiah. Dalam seri buku Kisah Para Nabi Pra-Ibrahim keduanya bersinergi menjelaskan kisah al-Qur'an. Dialog ayat-ayat kisah alQur'an dengan sains terlihat begitu kental, di mana temuan ilmiah dalam hal ini tidak dalam rangka menjelaskan kisah al-Qur'an secara rigid, seperti sistematika buku-buku ilmiah lainnya. Ia ditempatkan sebagai dalil pembuktian dan penjelasan atas beberapa kasus terkait kisah yang disusun berdasarkan tematama.

Sebagai contoh, pada kisah Nabi Adam, bahasan dibagi menjadi lima bagian, yakni: [1] Manusia pertama, [2] Nabi Adam dalam al-Qur'an, [3] beberapa catatan penting tentang riwayat Nabi Adam [4] hikmah dari kisah Nabi Adam [5] hikmah dari kisah dua putra Adam. Dari kelima tema bahasan ini, hanya tema ketiga yang mendapat penjelasan sains. Di antara beberapa catatan penting tentang riwayat Nabi Adam adalah respon malaikat terhadap penciptaan Nabi Adam. Penjelasan ini mengambil surat al-Baqarah/2 ayat ke-30 sebagai dalilnya. Data sains yang diketengahkan untuk menjelaskan ayat ini adalah [1] malaikat diciptakan dari cahaya, gelombang elektromagnetik sehingga ia dapat menembus ruang dan waktu dan dengan demikian malaikat telah mengetahui tabiat manusia di masa mendatang, bahwa manusia akan merusak lingkungan dan gemar berperang. [2] Pengungkapan adanya makhluk mirip manusia atau manusia purba telah lebih dahulu hadir di bumi sebelum Adam diciptakan, seperti Sabelanthropus ( 7 juta tahun yang lalu), Orrarin (6 juta tahun yang lalu), Ardipithecus (5,5-4-5 juta tahun yang lalu), Australepithecus (4-2 juta tahun yang lalu), Paratropus (3-1,2 juta tahun yang lalu), dan Homo (2 juta tahun yang lalu -sekarang), dimana semua jenis manusia purba ini sering berperang satu sama lain dan membuat kerusakan di bumi. Dua temuan ilmiah ini dipandang sebagai bukti kebenaran faktual untuk menjelaskan argumentasi malaikat ketika "membantah" keinginan Tuhan menciptakan khalifah di muka bumi dengan dalih mereka telah tahu sejak semua tabiat manusia yang cenderung negatif itu. ${ }^{32}$

32Ibid., 28-30. 
Demikian juga pada sub tema yang sama tentang kemampuan Adam dalam menjelaskan nama-nama benda terkait keterangan QS. al-Baqarah/2 ayat 31-33. Untuk mengonfirmasi kebenaran ini, dikutip tiga ayat terkait, yakni: QS. Al-Mu'minûn/24: 12 (sari pati tanah), QS. Al-Hijr/15: 26 (lumpur), dan QS. AlRahman/55:14 (tanah kering seperti tembikar). Unsur pembentuk manusia berdasarkan tiga ayat di atas adalah tanah, air (lumpur $=$ tanah + air), dan tembikar. Hal ini kemudian dijelaskan dengan data sain terkait unsur kima yang terdapat dalam tanah. Seperti dijelaskan bahwa unsur tanah terdiri dari besi $(\mathrm{Fe})$, tembaga $(\mathrm{Cu})$, kobalt $(\mathrm{Co})$, mangan $(\mathrm{Mn})$ dan unsur air hidrogen $(\mathrm{H})$, nitrogen $(\mathrm{N})$, fosfor $(\mathrm{P})$, dan oksigen $(\mathrm{O})$. Semua unsur-unsur metal dan metaloid akan menjadi katalis dalam proses reaksi kimia dan biokimia yang kemudian membentuk molekul kompleks, seperti ureum, asam amino, dan nukleotida. Sementara tembikar digunakan sebagai katalis dalam proses perpanjangan rantai kimia (polimer) dari molekul menjadi makromolekul, supramakromolekul, dan jaringan sel tubuh manusia, termasuk sel otak dan DNA. Sel otak inilah yang kemudian berfungsi menyimpan informasi, sementara DNA-kromosom berfungsi menyimpan informasi genetik manusia. ${ }^{33}$

Dua penjelasan tema diatas berbeda dengan tema-tema lain yang tidak mendapat penjelasan temuan ilmiah, seperti kutukan kepada iblis, tantangan iblis, Adam dan istrinya tinggal di surga dan tergoda setan, larangan yang dilanggar oleh Adam dan istrinya, dan lain-lain. Selain itu, Tafsir Ilmi tidak menjelaskan keseluruhan ayat yang berkaitan dengan kisah. Di dalam al-Qur'an terdapat 25 ayat dalam sembilan surat (al-Baqarah, al-Mâidah, Âli Imrân, alA'râf, al-Isrâ', al-Kahfi, Maryâm, Thaha, dan surat Yâsin) yang menggunakan term Adam, ${ }^{34}$ Jumlah ini belum termasuk korelasi ayat, baik sebelum maupun sesudahnya yang menguraikan tentang kisah Adam. Dari sembilan surat tersebut hanya lima surat yang dikutip (al-Baqarah, al-Mâidah, Âli Imrân, al-A'râf, al-Isrâ', dan, Thaha). Dari kelima surat ini terdapat 36 ayat yang dikutip dan dari jumlah itu hanya 11 ayat yang mendapatkan penjelasan sains. Ini dibahas dalam tiga tema, yakni: [1] QS. al-Baqarah/2: 30 tentang respon malaikat terhadap penciptaan Adam terkait pengetahuan malaikat terhadap realitas manusia di bumi, [2] QS. al-Baqarah/2: 31-33 tentang kemampuan Adam dalam menjelaskan nama-nama benda, terkait dengan asal ciptaan manusia dan [3] QS. al-Baqarah/2: 36-39; dan QS. Thaha/20: 122-124 tentang Adam turun ke bumi terkait tempat ia diturunkan. ${ }^{35}$

Secara kuantitatif, penjelasan sains terhadap ayat kisah al-Qur'an relatif sedikit, namun perlu digarisbawahi bahwa tidak semua hal terkait kisah dapat

\footnotetext{
${ }^{33}$ Ibid., 30-34.

${ }^{34}$ Lihat: Zaghlul al-Najjar, Min Ayât Al-I'jâz al-Inbâ'îwa al-Târîkbî Fi al-Qur'ân al-Karîm (Beirut: Dar al-Ma'rifah, 2013), j. 1, 32.

${ }^{35}$ Lajnah Pentashihan Mushaf al-Qur'an, Kisah Para Nabi Pra-Ibrabim Dalam Perspektif alQur'an Dan Sains, 27-52.
} 
dijelaskan oleh temuan ilmiah. Hal ini bisa disebabkan keterbatasan sains di satu sisi dan sifat kisah-kisah al-Qur'an itu sendiri yang metafisik sehingga sulit/ tidak bisa dikonfirmasi secara empiris di sisi lain. Keterbatasan ini tidak menjadikan kebenaran kisah al-Qur'an itu absurd atau tidak diakui secara ilmiah. Sebab, dalam perspektif filsafat ilmu kontemporer, menurut Mohammad Muslih, terdapat tiga model pengembangan sains. Pertama: pengembangan sains yang menekankan basis metodologi ilmiah. Model ini hanya dapat mengakui kebenaran ilmiah yang lahir dari metodologi ilmiah, teori ilmiah atau filsafat sains. Model ini lebih dekat dengan positivism-empiris. Kedua: kedua pengembangan sains berbasis metodologi ilmiah dan basis sosio-historis. Model ini kemudian dapat mengakui keberadaan ilmu-ilmu humaniora dan ilmu-ilmu sosial lainnya. Ketiga: pengembangan sains menekankan pada tiga basis keilmuan sekaligus, basis metodologi ilmiah, basis sosio-historis, dan basis teologimetafisis. ${ }^{36}$ Model ketiga ini memungkinkan pengembangan ilmu pengetahuan berbasis agama, termasuk kisah al-Qur'an, dapat diakui sebagai bagian yang tidak terpisah dari sains secara objektif.

Ketiga, penjelasan kisah dengan sumber israiliyat dan kitab suci lain. Dalam konteks teori integrasi kuantum pada Tafsir Ilmi, pola penafsiran berlapis juga dapat dilihat dari penggunaan sumberisrailiyatdankitab suci lain, seperti Perjanjian Lama.Terkait riwayat israiliyat, tim penyusun menegaskan:

Riwayat tersebut tidak dimaksudkan sebagai sumber kebenaran informasi agama, melainkan hanya memaparkan informasi kesejarahan yang terdapat dalam literatur klasik selain pelajaran ('ibrah) yang dapat diambil darinya - satu hal yang diharapkan dapat membuka wawasan kita tentang keterkaitan agama-agama dalam sejarah kemanusiaan. Wallâbua'lam. ${ }^{37}$

Terkait kitab suci agama lain, tim penyusun menyebutnya dengan analogi historis dalam rangka menganalisa data secara komparatif. ${ }^{38} \mathrm{Hemat}$ penulis, cara ini bertujuan agar tidak terjadi klaim kebenaran tunggal pada satu kitab suci saja. Biasanya, kitab suci lain diposisikan sebagai pembanding guna mengonfirmasi penjelasan al-Quran dan sains tentang sesuatu fakta sejarah dalam sebuah kisah.Sebagai contoh, penjelasan Tafsir Ilmi tentang bahan material bahtera Nabi Nuh dari papan kayu dan pasak yang dijelaskan dalam Qs. al-Qamar/54:13: "Dan Kami angkut dia (Nub) ke atas (kapal) yang terbuat dari papan dan pasak." Untuk

${ }^{36}$ M. Muslih, "Sains Islam Dalam Diskursus Filsafat Ilmu," KALAM 8, no. 1 (2014): 1-26, doi:10.24042/klm.v8i1.162.

${ }^{37}$ Lajnah Pentashihan Mushaf al-Qur'an, Kisah Para Nabi Pra-Ibrabim Dalam Perspektif alQur'an Dan Sains, 11.

${ }^{38}$ Muslih, "Sains Islam Dalam Diskursus Filsafat Ilmu." 
mengonfirmasi penjelasan ayat ini, Tim Penulis memaparkan penjelasan kitab Torah (Kitab Kejadian dalam Perjanjian Lama. Dalam kitab ini disebutkan:

"Buatlah olehmu sebuah bahtera dari gopher wood (kayu gofer). Jadikan beberapa ruangan di dalamnya, dan tutuplah di luar dan di dalam dengan pitc. Demikianlah, kamu harus membuatnya; panjang babtera itu harus 300 cubits, lebarnya 50 cubits, dan tingginya 30 cubits..." 39

Terkait ukuran Bahtera, al-Qur'an mengisyaratkan bahwa bahtera itu sangat besar mampu mengangkut semua jenis hewan dan manusia (Qs. Hud/11: 40). Ukuran detailnya diambil dari penjelasan di atas. Diperkirakan 1 cubits itu sama dengan 1,5 kaki. Jadi ukuran Bahtera Nabi Nuh menurut perjanjian lama ialah: panjang 450 kaki (150 meter), lebar 75 kaki (25 meter), dan tinggi 45 kaki (15 meter). Demikian juga ketika menjelaskan lokasi berlabuh bahtera Nabi Nuh, antara al-Quran dan Perjanjian Lama terdapat sedikit perbedaan. Dalam QS. Hûd/11: 44 menyebutkan bahtera itu berlabuh di Gunung Judi. Sementara perjanjian lama menyebutkan di pegunungan Ararat. Kedua lokasi ini terletak di perbatasan Iran-Turki-Armenia. Gunung Judi berjarak sekitar $320 \mathrm{~km}$ dari rangkaian pegunungan Ararat tersebut. Artinya, gunung Jadi masih merupakan rangkaian dari Pegunungan Ararat. Hasil komparasi antara al-Quran dan kitab suci lain pada penjelasan kisah tertentu bisa berujung memperkuat informasi kesejarahan peradaban manusia.

\section{Falsifikasi Teistis}

Rekonsiliasi metodologi antara agama dan sains dipandang menjadi solusi bagi keduanya untuk saling berinteraksi dan berdialog secara integratif. Guessoum menyarankan pola penerapan integrasi berbasis falsifikasi teistis yang terkait dengan aspek metodologi dan metafisis. Aspek falsifikasi berkaitan dengan aturan bagaimana sistematika kerja sains. Sementara, basis metafisis yang ditarik dari ajaran agama sebagai worldview (pandangan dunia) teistik guna memahami aspek-aspek spiritual moral. Pengungkapan kisah para Nabi PraIbrahim dalam Tafsir Ilmi tidak terlepas kedua aspek ini.

Pertama, penerapan pola falsifikasi dalam integrasi kisah al-Qur'an dan sains, hemat penulis, telah melalui metodologi yang ketat meskipun masih ditemukan data-data dianggap lemah. Salah satu prinsip dasar yang digunakan penyusun Tafsir Ilmi adalah menerima temuan ilmiah yang telah mencapai tingkat hakikat, bukan teori atau hipotesis yang belum teruji kebenarannya. Data-data sains yang digunakan untuk menjelaskan kisah al-Qur'an adalah hasil dari rangkaian prosedur ilmiah yang telah tervalidasi dan terverfikasi. Hal senada juga disarankan Wilber, aspek falsifikasi dalam pandangan Wilber merupakan serangkaian metodologi bagaimana agama dan sains berintegrasi secara logis

${ }^{39}$ Lajnah Pentashihan Mushaf al-Qur'an, Kisah Para Nabi Pra-Ibrabim Dalam Perspektif alQur'an Dan Sains, 61. 
dalam upaya verifikasi dan memperoleh pengetahuan yang valid. Untuk sampai pada maksud tersebut, ia menyarankan agar peneliti melakukan pemeriksaan atas hasil penelitian berdasarkan data dan bukti yang meyakinkan, baik untuk ditolak, diterima atau sebagai bukti penguat. ${ }^{40}$

Umumnya temuan sains dalam Tafsir Ilmidigunakan sebagai bukti penguat kisah para Nabi Pra-Ibrahim. Misalnya unta betina Nabi Shalih, yang disebutkan dalam beberapa ayat al-Qur'an ${ }^{41}$ sebagai mukjizat Nabi Shalih. Air susuunta ini mampu memberi minum seluruh penduduk negeri kaum Samud. Sebagai penguat, disertakan hasil penelitian ilmiah tentang kemampuan unta. Unta mampu minum air 130 liter air dalam sekali teguk. Penelitian Fatimah Abdur Rahman ahli mikrobiologi menemukan bahwa susu unta lebih bergizi dari susu sapi; kadar lemak dan kolesterol rendah; kaya zat besi dan meneral seperti: kalium, natrium, dan magnesium. Di akhir penjelasandiungkap pernyataan sebagai penegas dan penguat: "unta Nabi Shalih tentu mempunyai semua kriteria kelebihan itu dibanding unta biasa, yang mempunyai banyak kelebihan seperti disebut di atas.

Kedua, Aspek metafisis dalam kerangka sains teistis yang disarankan Guessoum, menekankan worldview kisah sebagai bagian dari aspek teologis. Upaya menyingkap aspek teologissengaja dihadirkan dalam tafsir ilmu guna menggugah kesadaran spiritualitas dan moralitas pembaca. Sebagai contoh, kaum 'Ad menurut keterangan al-Qur'an adalah kaum yang telah mampu mencapai peradaban yang cukup tinggi di zamannya, namun mereka sombong, kufur, keras dan sangat kejam kepada warganya. Allah kemudian menghancurkan mereka dengan mendatangkan ingin topan yang sangat dahsyat. ${ }^{42}$ Sisi spiritual-moral dari kisah ini menegaskan bahwa peradaban yang telah dianggap maju dengan capaian-capaian yang belum pernah dicapai oleh manusia di negeri manapun pada saat itu, tidak ada nilainya jika tidak tunduk pada Sang Pencipta. Bagi masyarakat kontemporer hal ini sangat penting untuk diinsafi.

Selain itu, perilaku penguasa yang keras dan kejam terhadap warganya juga menjadi penyebab pemusnahan kaum 'Ad. ${ }^{43}$ Dalam konteks masyarakat kontemporer hal ini mengingatkan akan pentingnya hubungan penguasa dan yang dikuasai dalam mewujudkan nilai-nilai keadilan, baik dalam politik, hukum, ekonomi, maupun sosial. Pola hubungan yang tidak seimbang antara penguasa

\footnotetext{
${ }^{40}$ Ken Wilber, The Marriage Of Sense And Soul Integrating Science And Religion (Canada: Random House, 2009).

${ }^{41}$ Qs. al-A'raf/7: 73; Hud/11: 64; al-Syu'ara/26:155-156; dan al-Qamar/54: 27-31.

42 QS. al-Syu'arâ/26: 128-130; al-Fussilât/41: 15-16; al-Ahqâf/46: 24-25; al-Qamar/54: 18-20; al-Haqqah/69: 6-7

${ }^{43}$ QS. al-Syu'arâ'/26: 130
} 
dan yang dikuasai yang menampilkan hegemoni negara atas masyarakat yang pada akhirnya akan menciptakan kesenjangan sosial dan tentu saja akan berdampak pada sektor lain. Lahirnya berbagai persoalan seperti terorisme, kriminal, kemiskinan, krisis lingkungan, dan lain-lain tidak terlepas pola hubungan antara penguasa dan yang dikuasai yang cenderung monarki. Kasus kaum 'Ad adalah representasi dari kesenjangan hubungan penguasa dan yang dikuasai dalam konteks historis. Hubungan penguasa dan yang dikuasai semestinya dipahami sebagai hubungan simbiosis mutualistis, yakni hubungan yang saling menguntungkan antara kedua belah pihak. Masing-masing pihak dapat berfungsi sebagai objek dan subjek sekaligus, bukan salah satu subjek dan yang lain adalah objek.

Salah satu aspek terpenting dari kisah al-Qur'an dalam studi 'Ulum alQur'an adalah menarik inti kisah sebagai pengajaran bagi manusia. ${ }^{44}$ Untuk memperoleh nilai-nilai pengajaran dari kisah, maka harus melalui proses internalisasi. Internalisasi al-Qur'an merupakan proses peresapan, penghayatan dan penanaman nilai-nilai spiritual dan moral. ${ }^{45}$ Internalisasi upaya penyemaian nilai-nilai yang diserap dari kisah al-Qur'an melalui proses objektivikasi rasional untuk kemudian dapat dipahami, dihayati, dan diamalkan secara relevan. Sebagai contoh, respon Malaikat atas penciptaan khalifah di muka bumi. Realitas kehidupan manusia, dari purba hingga modern menunjukkan adanya kecenderungan seperti yang dikhawatirkan Malaikat, yakni merusak bumi dan saling berperang, menumpahkan darah satu sama lain. ${ }^{46} \mathrm{Hal}$ ini seolah ingin mengingatkan manusia akan posisinya sebagai khalifah di muka bumi yang memiliki tanggung jawab spiritual-vertikal kepada Penciptanya dan tanggungjawab moral- horizontal kepada diri sendiri, sesama manusia, dan kepada alam semesta, dimana relasi harmonis pada empat elemen ini harus dipelihara dengan baik.

\section{Kesimpulan}

Tafsir Ilmi: Kisah Para Nabi Pra-Ibrabim dalam Perseptif al-Qur'an dan Sains merupakan hasil integrasi tafsir al-Qur'an dan sains. Penelitian ini mengungkap tiga pola integrasi dalam karya tersebut berdasarkan teori integrasi kuantum. Pertama, pola integrasi kisah al-Qur'an dan sains menekankan prinsip tidak ada pertentangan antara al-Qur'an dan sains. Hal ini dibuktikan dari adanya titik kesamaan penyajian kisah Para Nabi Pra-Ibrahami dan temuan sains pada sisi sumber, tujuan, metode, dan konten. Kedua, integrasi kisah al-Qur'an dan sains

${ }^{44}$ QS. Hûd/11: 120 dan QS. Yûsûf/12: 111

${ }^{45}$ Lutfi, Epistemologi Tafsir Sains Zaghlûl Al-Najjâr (Magelang: PKBM Ngudi Ilmu, 2013), 85.

${ }^{46}$ Lajnah Pentashihan Mushaf al-Qur'an, Kisah Para Nabi Pra-Ibrabim Dalam Perspektif alQur'an Dan Sains, 28-30. 
memakai pola penafsiran berlapis dalam hal penggunaan sumber, baik dari tradisi tafsir, temuan ilmiah, maupun riwayat israiliyat dan kitab suci lain. Upaya ini menekankan bahwa tidak ada kebenaran tunggal pada informasi kesejarahan peradaban manusia. Ketiga, pola falsifikasi teistik membuktikan struktur integrasi yang diterapkan dalam Tafsir Ilmi, menekankan aspek metodologi dan metafisik. Aspek metodologi mengutamakan pemeriksaan data hasil penelitian berdasarkan data dan bukti yang meyakinkan yang digunakan sebagai bukti penguat kisah alQur'an. Sementara aspek metafisik merupakan penyimpulan kisah sebagai worldview teistis.

Secara khusus, spekteistis dari Kisah Para Nabi Pra-Ibrahim memperlihatkan adanya proses internalisasi nilai-nilai spiritual-moral melalui pandangan objektif tentang hikmah kisah al-Qur'an. Internalisasi dalam konteks kisah al-Qur'an merupakan penyemaian nilai-nilai yang diserap melalui kisahkisah tersebut melalui proses objektivikasi rasional untuk kemudian dapat dipahami, dihayati, dan diamalkan secara relevan. Di antara nilai-nilai spiritualmoral yang dapat ditangkap melalui Kisah Para Nabi Pra-Ibrahim, adalah pentingnya menjaga relasi harmonis baik secara vertikal dengan Allah SW'T maupun horizontal dengan diri sendiri, sesama manusia, dan alam semesta.

\section{Bibliografi}

Abd al-Baqi, Muhammad Fu'ad. Al-Mu'jam al-Mufahras Li Alfazh al-Qur'an alKarim. Beirut: Dar Al-Fikr, 1417.

Abu Zaid, Nasr Hamid. Teks Otoritas Kebenaran. Yogyakarta: LKiS, 2012.

Ahmad Ibn Fâris Ibn Zakaria, Muhammad Abi al-Husain. Mu'jam Maqâyiz alLughah. Beirut: Dar Ihya al-Turats Arabi, 2001.

Asfahaniy, Al-Raghib al-. Mufradât Alfâz Al-Qur'ân. Damaskus: Dar al-'Ilm, 2002.

Baihaqi, Yusuf. "Dimensi Sains Dalam Kisah Al-Qur'an Dan Relevansinya Dengan Keakuratan Pemilihan Kata." Jurnal Aqlam 3, no. 2 (2018): 266-80.

Faizin. "Integrasi Agama Dan Sains Dalam Tafsir Ilmi Kementerian Agama RI." Jurnal Ushuluddin 25, no. 1 (2017): 19-33. doi:10.24014/jush.v25i1.2560.

Hamzah, Asâmah Muhammad Abdul 'Azhîm. Al-Qashash al-Qur'anî Wa Atsaruhu Fi Isbâth al-Ahkâm. Kairo, 2008.

Hanafi, Muchlis M. "Memahami Isyarat-Isyarat Ilmiah al-Qur'an: Sebuah Pengantar." In Kisah Para Nabi Pra-Ibrahim Dalam Perspektif al- 
96 | AL QUDS : Jurnal Studi Alquran dan Hadis vol. 4, no 1, 2020

Qur'an Dan Sains, by Lajnah Pentashihan Mushaf al-Qur'an. Jakarta: LPMA, 2012.

'Itr, Nur al-Dîn Muhammad. 'Ulum al-Qur'an al-Karim. Damaskus: Mathba'ah Shabâh, 1995.

Lajnah Pentashihan Mushaf al-Qur'an. Hewan Dalam Perspektif Al-Qur'an Dan Sains. Jakarta: LPMA, 2012.

. Kisah Para Nabi Pra-Ibrahim Dalam Perspektif al-Qur'an Dan Sains. Jakarta: LPMA, 2012.

Lutfi. Epistemologi Tafsir Sains Zaghlûl Al-Najjâr. Magelang: PKBM Ngudi Ilmu, 2013.

Mahalli, Jalâl al-Dîn Muhammad Ibn Ahmad al-, and Jalâl al-Dîn 'Abdurrahman Ibn Abi Bakr al-Suyûthî. Tafsir Jalalain. Kairo: Dar al-Hadits, n.d.

Maraghi, Ahmad Ibn al-Musthafâ al-. Tafsir Al-Maraghi. Mesir: al-Bâb al-Halabî, 1946.

Muslih, M. "Sains Islam Dalam Diskursus Filsafat Ilmu." KALAM 8, no. 1 (2014): 1-26. doi:10.24042/klm.v8i1.162.

Naisabûri, Abu Ishaq Ahmad Ibn Muhammad Ibn Ibrâhîm al-. Qashash AlAnbiya'. Beirut: Dar Al-Fikr, n.d.

Najjar, Zaghlul al-. Min Ayât Al-I'jâz al-Inbâ'îwa al-Târîkhî Fi al-Qur'ân alKarîm. Beirut: Dar al-Ma'rifah, 2013.

Nidhal Guessoum. Islam's Quantum Question: Reconciling Muslim Tradition and Modern Science. London: I.B. Tauris, 2011.

Qaththân, Manna al-. Mabahits Fi 'Ulum al-Qur'An. Kairo: Maktabah Wahbah, 2000 .

Ridha, Muhammad Rasyid. Tafsîr Al-Manar. Mesir: Hai'ah Mishriyah, 1990.

Shihab, M. Quraish. Kaedah Tafsir. Tangerang: Lentera Hati, 2013.

Soleh, Achmad Khudori. "Pendekatan Kuantum Dalam Integrasi Agama Dan Sains Nidhal Guessoum.” ULUL ALBAB Jurnal Studi Islam 19, no. 1 (2018): 119. doi:10.18860/ua.v19i1.4937.

Wilber, Ken. The Marriage Of Sense And Soul Integrating Science And Religion. Canada: Random House, 2009. 